\title{
Astrocytes as a source for extracellular matrix molecules and cytokines
}

\author{
Stefan Wiese ${ }^{1}{ }^{*}$, Michael Karus $^{2}$ and Andreas Faissner ${ }^{2 *}$ \\ ' Group for Molecular Cell Biology, Department for Cell Morphology and Molecular Neurobiology, Ruhr-University Bochum, Bochum, Germany \\ ${ }^{2}$ Department for Cell Morphology and Molecular Neurobiology, Ruhr-University Bochum, Bochum, Germany
}

Edited by:

Roberto C. Sotero, McGill University,

Canada

Reviewed by:

Alexander Dityatev, Italian Institute of Technology, Italy

Renato Frischknecht, Leibniz Institute

for Neuroscience, Germany

${ }^{*}$ Correspondence:

Stefan Wiese and Andreas Faissner

Department for Cell Morphology and

Molecular Neurobiology,

Ruhr-University Bochum,

Universitaetsstr. 150, D-44801

Bochum, Germany.

e-mail: stefan.wiese@rub.de;

andreas.faissner@rub.de
Research of the past 25 years has shown that astrocytes do more than participating and building up the blood-brain barrier and detoxify the active synapse by reuptake of neurotransmitters and ions. Indeed, astrocytes express neurotransmitter receptors and, as a consequence, respond to stimuli. Within the tripartite synapse, the astrocytes owe more and more importance. Besides the functional aspects the differentiation of astrocytes has gained a more intensive focus. Deeper knowledge of the differentiation processes during development of the central nervous system might help explaining and even help treating neurological diseases like Alzheimer's disease, Amyotrophic lateral sclerosis, Parkinsons disease, and psychiatric disorders in which astrocytes have been shown to play a role. Specific differentiation of neural stem cells toward the astroglial lineage is performed as a multi-step process. Astrocytes and oligodendrocytes develop from a multipotent stem cell that prior to this has produced primarily neuronal precursor cells. This switch toward the more astroglial differentiation is regulated by a change in receptor composition on the cell surface and responsiveness to Fibroblast growth factor and Epidermal growth factor (EGF). The glial precursor cell is driven into the astroglial direction by signaling molecules like Ciliary neurotrophic factor, Bone Morphogenetic Proteins, and EGF. However, the early astrocytes influence their environment not only by releasing and responding to diverse soluble factors but also express a wide range of extracellular matrix (ECM) molecules, in particular proteoglycans of the lectican family and tenascins. Lately these ECM molecules have been shown to participate in glial development. In this regard, especially the matrix protein Tenascin C (Tnc) proved to be an important regulator of astrocyte precursor cell proliferation and migration during spinal cord development. Nevertheless, ECM molecules expressed by reactive astrocytes are also known to act mostly in an inhibitory fashion under pathophysiological conditions. Thus, we further summarize resent data concerning the role of chondroitin sulfate proteoglycans and Tnc under pathological conditions.

Keywords: astroglial development, extracellular matrix, Tenascin-c, cytokines, reactive astrocytes

\section{INTRODUCTION}

When the neuroglial cells were first described, these cells were thought to act as connective cells that subdivide neurons into clusters of cells in the brain, spinal cord, and nerves (Virchow, 1856). Later this connective tissue was named glia ("glue") that can be distinguished from nerve cells within the brain and the peripheral nervous system (PNS). Glial cells include primarily oligodendrocytes and astrocytes in the central nervous system (CNS) and Schwann cells in the PNS. In addition, the brain "immune cells," the microglia are the immune competent macrophages of the CNS (Kauppinen et al., 1989; Volterra and Meldolesi, 2005; De Keyser et al., 2008; Allen and Barres, 2009; Kettenmann and Verkhratsky, 2011). While oligodendrocytes and Schwann cells mainly function as myelin producing cells ensheathing the axon in the central and PNS, the astrocytes have long been thought to have a structural function, providing energy, detoxifying the synapses, and building up the blood-brain barrier, rather than an active role in neurotransmission (Kettenmann and Verkhratsky, 2011). Astrocytes represent the major brain cell component (20-50\%). They send out numerous processes and locally contact the surrounding cells, neurons, other glial cells, and endothelial cells. Besides the pure barrier function, they also play a vital role in the control of cerebral blood flow and the glucose homeostasis of the brain as this is the main energy source for the brain. For review (see Sofroniew and Vinters, 2009).

Within the developing brain and spinal cord Neural stem cell precursor cells (NSPCs) generate neuronal cells in the first place. Changes in the expression of growth factor receptors subsequently result in the specification of astroglial cells (see also Table 1). Here, it has been shown that the expression of the epidermal growth factor (EGF)-Receptor seems to be necessary for normal astrocyte development (Kornblum et al., 1998). While initial PDGF and FGF2 signals form these cells the cells themselves turn to a PDGF$\mathrm{R}$ negative precursor cell (see also Figure 1). In general, the cells are then characterized by expression of A2B5, Nestin and PLP, and the fibroblast growth factor (FGF)-Receptor. 
Table 1 | Stage dependent marker expression for the astroglial differentiation lineage.

\begin{tabular}{|c|c|c|c|c|c|}
\hline Marker & Early precursor cell & Late precursor cell & Astrocyte precursor & Mature astrocyte & Citations \\
\hline Nestin & + & + & - & - & Rauch et al. (1997), Kornblum et al. (1998) \\
\hline BLBP & + & + & - & - & Rauch et al. (1997), Kornblum et al. (1998) \\
\hline FGFR & + & + & - & - & Kornblum et al. (1998) \\
\hline GLAST & - & + & + & + & Lehre et al. (1995) \\
\hline EGFR & - & + & $+?$ & - & Karus et al. (2011) \\
\hline Tnc & - & + & + & - & Lehre et al. (1995), Karus et al. (2011) \\
\hline FGFR3 & - & - & + & + & Cahoy et al. (2008) \\
\hline$S 100 \beta$ & - & - & + & + & Nagelhus et al. (2004) \\
\hline Aqp4 & - & - & + & + & Nagelhus et al. (2004) \\
\hline AldH1L1 & - & - & + & + & Cahoy et al. (2008) \\
\hline GFAP & - & - & - & + & Meeuwsen et al. (2003) \\
\hline
\end{tabular}

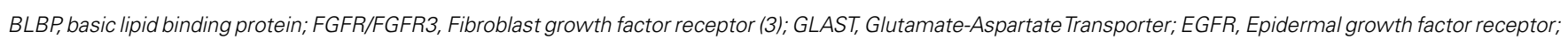
Tnc, Tenascin C; Aqp4, Aquaporin 4; AldH1L1, Aldehyde dehydrogenase 1, member L1; GFAP, Glial fibrillary acidic protein.

The maturation of astrocytes is also accompanied by the expression of a wide variety of chondroitin sulfate proteoglycans (CSPGs) like brevican, neurocan, versican and aggrecan, and extracellular matrix (ECM) proteins, namely Tnc, that are released to the ECM compartment but have also impact on the astrocytes themselves. This gains importance as the glial scar has been shown to reexpress, e.g., Tnc that can highly influence the regenerative capacity to its worse in Human and mammals (Sofroniew and Vinters, 2009). In this review we will therefore first focus on the development of astrocytes in the CNS with respect to functions of the ECM therein and then take a closer look to functional aspects of soluble factors and ECM molecules in health and disease.

\section{THE NEURAL EXTRACELLULAR MATRIX: COMPOSITION AND FUNCTIONAL ASPECTS FOR ASTROCYTE DEVELOPMENT}

Cells in connective tissues are embedded in an ECM that not only binds the cells together but also influences their survival, development, shape, polarity, and behavior. The ECM includes various protein fibers interwoven in a hydrated gel (Maleski and Hockfield, 1997; Rauch et al., 1997). In general this interwoven meshwork comprises fibrillar proteins (e.g., collagens), glycoproteins (e.g., laminins, fibronectin, tenascins), and several classes of proteoglycans (heparan sulfate-, chondroitin sulfate-, dermatan sulfate-, and keratan sulfate proteoglycans). The latter mainly consist of large glycosaminoglycan (GAG) chains, covalently linked to extracellular or membrane bound core proteins. In contrast to other tissues, the ECM in the CNS lacks fibrillar proteins under physiological conditions. Instead the neural ECM is rich in glycoproteins and proteoglycans. It has been estimated that the neural ECM makes up about $20 \%$ of the CNS parenchyma (Nicholson and Sykova, 1998). Therefore, it is not surprising, that several studies in the last decades demonstrated important functions of distinct ECM molecules in the developing as well as in the adult CNS. During the early development of the CNS the overall expression of ECM molecules is relatively low and subsequently increases toward the end of embryogenesis and during postnatal development. However, the germinal layers already contain distinct ECM components and their cognate receptors during neurogenesis in the developing cortex (Ford-Perriss et al., 2003; von Holst et al.,
2006; Lathia et al., 2007; Moritz et al., 2008). In the adult CNS several ECM molecules are prominently expressed in stem cell niches (Gates et al., 1995; von Holst et al., 2006; Kazanis et al., 2007).

\section{RADIAL GLIA STEM CELLS AND NEUROSPHERES EXPRESS CSPGs AND ECM MOLECULES}

Despite their prominent expression during neural development only little is known about the functional importance of specific CSPGs and ECM molecules for astrocyte development. In the following we summarize recent findings concerning the roles of CSPGs and members of the Tenascin family in the context of the cortical and spinal cord development. CSPGs consist of chondroitin sulfate GAG chains, covalently attached to a serine residue of a core protein (Kleene and Schachner, 2004). CSPGs have been shown to bind to FGF2 and modulate FGF signaling (Milev et al., 1998; Sirko et al., 2010a). Thus, they are perfectly suited for regulating neural development.

When exploring the ECM structure in the stem cell niche, we have shown in an earlier study that both phosphacan and the DSD1-epitope are enriched in the germinal zones of the adult CNS (Gates et al., 1995). Therefore, we have more closely examined the relationship of the DSD-1- (473HD-) epitope to the neural stem cell compartment during different stages of development. We provided evidence that both Neural stem cell precursor cells (NSPCs) and radial glia express the RPTP- $\beta / \zeta$-receptor and the 473HD-carbohydrate (Garwood et al., 2001; Faissner et al., 2006; von Holst et al., 2006). The structure targeted by monoclonal antibody (MAb) 473HD is enriched in the germinal layers during mouse forebrain development and can be considered a novel surface marker of radial glia (von Holst et al., 2006). This is consistent with the observation that CSPGs are released by NSPCs growing as neurospheres (Ida et al., 2006). Neurospheres are viewed as culture model of NSPCs that grow in suspension and comprise neural stem and committed progenitor cells. The neurospheres strongly express the $473 \mathrm{HD}$-epitope. Consistent with this observation, a compositional analysis detected a considerable variety of monoand di-sulfated disaccharide units in chondroitin sulfate/dermatan sulfate (CS/DS) chains purified from the embryonic mammalian CNS (Ueoka et al., 2000; Zou et al., 2003; Bao et al., 2005; Properzi 


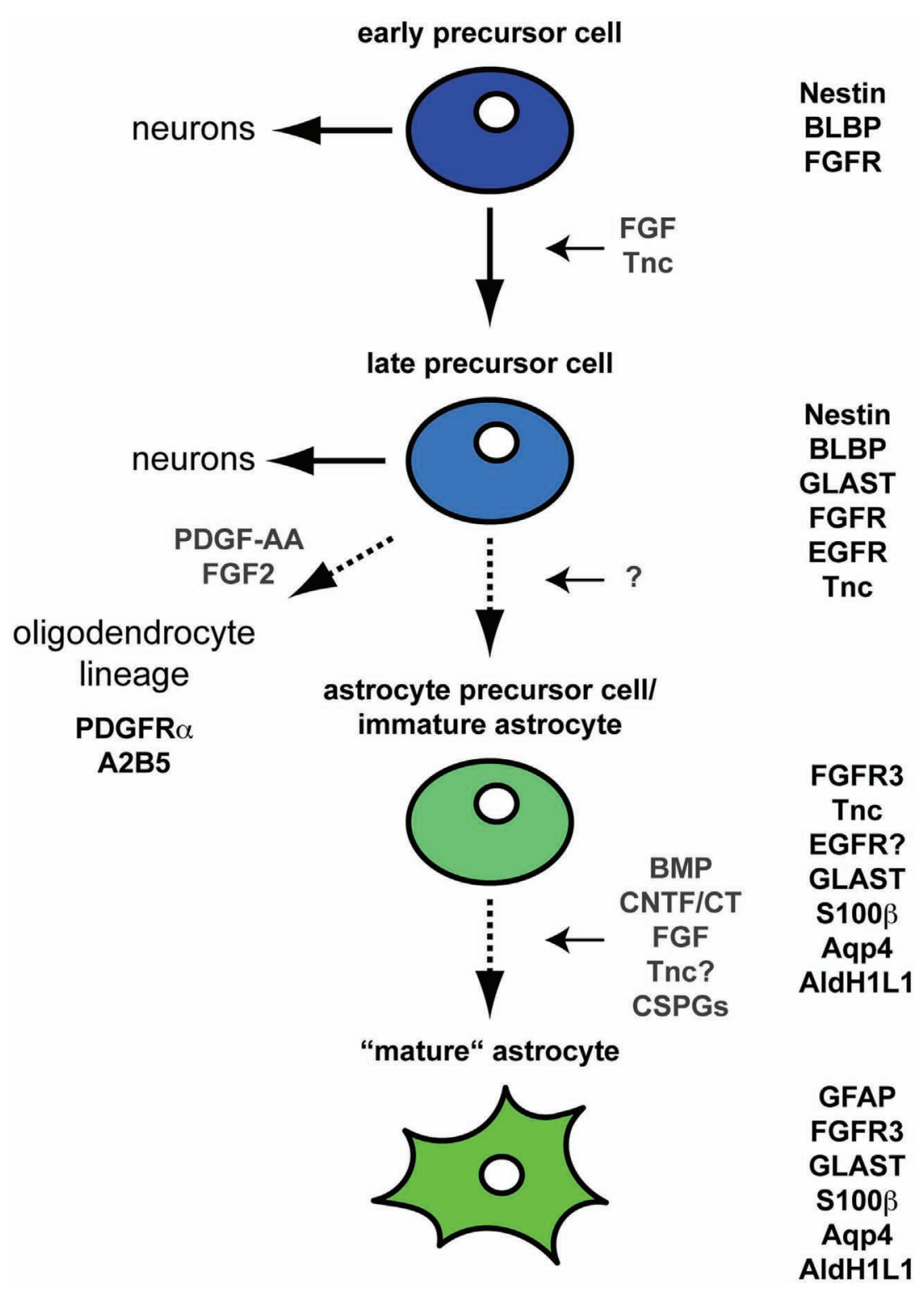

FIGURE 1 | Differentiation of astrocytes during CNS development Schematic illustration of the CNS astroglial lineage and its associated molecular markers. At early embryonic stages NSPCs expressing Nestin, $\mathrm{BLBP}$, and FGFRs primarily generate neurons. Upon sustained FGF signaling these NSPCs acquire an additional EGF responsiveness. The expression of the EGFR is also stimulated by Tnc (Karus et al., 2011). At that stage NPCs still generate neurons through intermediate progenitors at least in the embryonic cortex. In contrast, these EGF responsive NPCs appear to generate only few if any neurons in the embryonic spinal cord. Regardless of their location along the rostro-caudal axis these NPCs already share some molecular markers with astroglial cells such as GLAST and Tnc (Lehre et al., 1995). These cells also express additional markers such as $\mathrm{S} 100 \beta$, Aquaporin 4 (Nagelhus et al., 2004), Fibroblast growth factor receptor 3 (FGFR3), and Aldh1L1 (Cahoy et al., 2008). Subsequently the cells transform into GFAP-positive mature astrocytes often classified into fibrous white matter and protoplasmic gray matter astrocytes. In this context, soluble molecules such as CNTF/CT1, BMPs, and FGFs are known to regulate the GFAP expression (Meeuwsen et al., 2003). Moreover, CSPGs and potentially also Tnc are also involved in the maturation toward GFAP-positive astrocytes (Sirko et al., 2007). et al., 2005; Ida et al., 2006). CSPGs as well as CS specific sulfotransferases are expressed by both radial glia cells in the embryonic cortex and NSPCs cultivated as free floating neurospheres (Kabos et al., 2004; von Holst et al., 2006; Akita et al., 2008; Ishii and Maeda, 2008). To obtain functional insights into potential functions of the $473 \mathrm{HD}$-epitope, the MAb 473HD, or the enzyme chondroitinase $\mathrm{ABC}$ (ChABC) were added to neurosphere cultures. Both treatments caused a reduction of the number of neurospheres and proliferating NSPCs (von Holst et al., 2006; Sirko et al., 2010b). Furthermore, the treatment with ChABC treatment favored the generation of the astrocyte lineage at the expense of neurogenesis (Sirko et al., 2007, 2010a). Altogether, these data clearly suggest that CS-GAGs are involved in controlling the pathway of NSPC expansion and differentiation. 
The enzymes that are required for the biosynthesis of CSGAGs sulfation patterns are detectable in neurospheres and in neurogenic regions of the developing and the adult CNS (Akita et al., 2008). With regard to astrocyte development, chicken embryos lacking the CSPG aggrecan exhibit an increased differentiation of astrocyte precursors toward GFAP-positive astrocytes (Domowicz et al., 2008). Along these lines the enzymatic degradation of CS-GAGs from telencephalic NSPCs promotes astroglial differentiation in vitro and in vivo (Sirko et al., 2007).

Besides CSPGs members of the Tenascin gene family recently gained much attention with regard to glial development owing to their late embryonic and early postnatal expression (Czopka et al., 2009; Karus et al., 2011). We have recently shown that Tnc regulates the maturation of astroglial cells during embryonic spinal cord development, primarily by orchestrating the growth factor responsiveness of NSPCs (Figure 1; Karus et al., 2011). This appears to be a common phenomenon, since a Tnc dependent regulation of growth factor responsiveness has also been shown for cortical NPCs (Garcion et al., 2004; Yagi et al., 2010). Tnc also modifies the expression of important neural patterning genes at the onset of gliogenesis in the developing spinal cord. However, on a cell biological level, the lack of Tnc affects gliogenic NSPC proliferation and migration (see also Figure 2; Karus et al., 2011). The effect on gliogenic NSPC proliferation is in line with a former report on primary human astrocytes, showing a Tnc dependent reduction in BrdU incorporation accompanied by reduced Nestin expression levels (Holley et al., 2005). In addition, Tnc lowers the Nestin expression level of rat NSPC derived astrocytes (Nash et al., 2011). Interestingly, both the adult cortex and the adult hippocampus of Tnc deficient animals contain more S100 $\beta$-positive astrocytes (Irintchev et al., 2005; Gurevicius et al., 2009). These phenotypes could be explained by changes of astrocyte proliferation and differentiation during development.

\section{MATURE ASTROCYTES EXPRESS, RELEASE, AND REGULATE PROTEOGLYCAN EXPRESSION IN HEALTH AND DISEASE}

Astrocytes express a large range of proteoglycans (see also Figure 2), both during development and after lesion, under which condition they contribute significantly to the glial scar. The proteoglycans are generally subdivided into two classes, the membrane-associated heparin sulfate proteoglycans (HSPGs) of the glypican and the syndecan subfamilies; and CSPGs of the lectican family such as brevican, neurocan, versican, and aggrecan that are mostly released into the extracellular environment
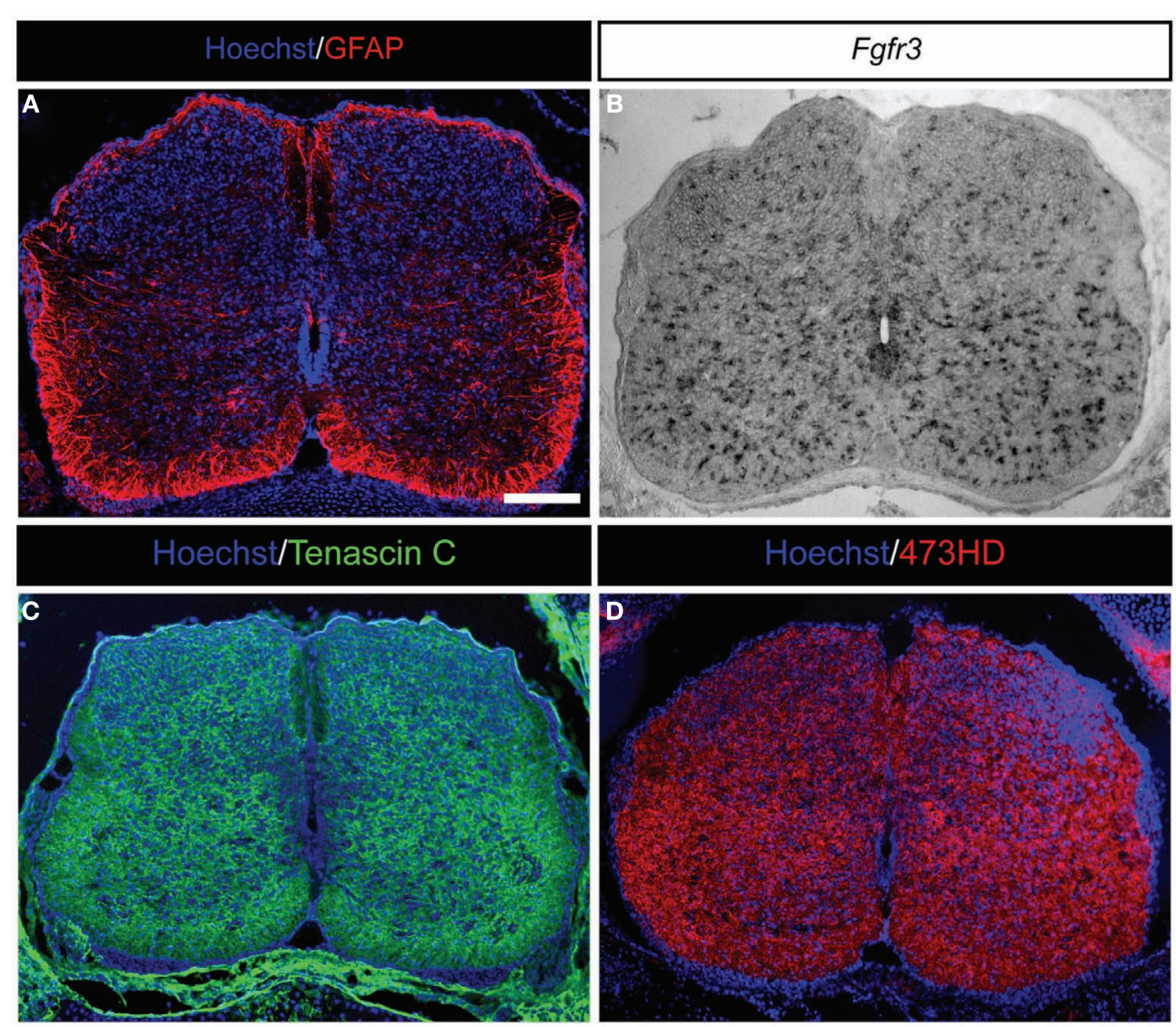

FIGURE 2 | Expression of astrocyte markers and ECM molecules in the developing mouse spinal cord. (A) GFAP-positive

astrocytes in the developing E18.5 mouse spinal cord are present predominantly in the white matter and within the later gray matter as migrating cells. (B) Moreover, Fgfr3-expressing astroglial cells are distributed throughout the whole spinal cord. (C) Additionally, the spinal cord is characterized by strong expression of ECM molecules, such as the glycoprotein Tenascin C or (D) glycosaminoglycans residues on proteoglycans detected by the $\mathrm{mAb} 473 \mathrm{HD}$. Scale bar: $100 \mu \mathrm{m}$. 
(Bandtlow and Zimmermann, 2000). HSPGs play important roles in FGF-2-signaling by recruiting the cytokine to its receptor FGFR. Furthermore, they have been implicated in supporting the signal transfer of morphogens such as Wnt-proteins that regulate neural stem cell proliferation.

Chondroitin sulfate proteoglycans are enriched in CNS scar tissue after lesions and thought to inhibit regeneration of axons (Smith-Thomas et al., 1994, 1995; Silver and Miller, 2004; Carulli et al., 2005; Properzi et al., 2005; Busch and Silver, 2007; Fitch and Silver, 2008; Galtrey et al., 2008; Kwok et al., 2008). In agreement with this view, the elimination of CSPGs with the bacterial enzyme ChABC improves functional recovery in the CNS after damage (Bradbury et al., 2002;Fawcett, 2006a,b; Fitch and Silver, 2008; Massey et al., 2008). The regeneration preventing properties of CSPGs and the potential therapeutic value of ChABC have been extensively commented in recent years (Verma et al., 2008; Fawcett, 2009). Yet, ChABC resistant inhibition has also been reported (Siddiqui et al., 2009). Beyond a role as obstacles to regeneration, CSPGs have also been implicated in the regulation of synaptic plasticity (Bradbury et al., 2002; Pizzorusso et al., 2002; Faissner et al., 2010). In this context the 473HD-epitope has been shown to be expressed on a subpopulation of GFAP- as well as nestinpositive cells in a laser lesion model of the adult rat visual cortex. Therefore, the 473HD-epitope as stem cell-marker designates the cells which generate the neurospheres that can be cultivated from the lesioned adult rat cortex (Sirko et al., 2009). This particular chondroitin sulfate motif has been discovered with the help of a MAb recognizing the 473HD-epitope (Faissner et al., 1994a; Gates et al., 1995). The structure has been designated as DSD-1-epitope, which is strongly enriched on phosphacan (Garwood et al., 1999, 2001). The DSD-1-glycosaminoglycan (GAG)-epitope is functionally active in that it promotes neurite outgrowth from several CNS neuron types (Faissner et al., 1994b; Garwood et al., 1999). The structural analysis revealed that the 473HD- (synonymous to DSD-1-) epitope requires sulfation and comprises the CS-Dtype chondroitin sulfate motif (Faissner et al., 1994b; Clement et al., 1998; Nadanaka et al., 1998; Hikino et al., 2003). Overall, the structure is characterized by sulfated hexa- or octasaccharide oligomers that differ from the binding sites of the monoclonal anti-chondroitin sulfate antibodies CS-56 or MO-225 (Ito et al., 2005).

\section{THE ECM GLYCOPROTEIN TENASCIN-C IS EXPRESSED AND REGULATED BY DEVELOPING AND REACTIVE ASTROCYTES}

Tenascin-C is a glycoprotein that is expressed in the ECM of various tissues where it regulates processes such as cell growth, migration, and adhesion during development (see also Figure 2), but also under pathological conditions in the adult, for example in tumors (Faissner, 1997a; Jones and Jones, 2000; Joester and Faissner, 2001; Chiquet-Ehrismann and Chiquet, 2003; ChiquetEhrismann and Tucker, 2011). Tnc is even involved in plasticity, memory, and learning by modulation of L-type $\mathrm{Ca}^{2+}$ channels and modulation via the fibronectin domains (Evers et al., 2002; Strekalova et al., 2002). Tnc is built up in a modular fashion and consists of a cysteine-rich amino-terminus, Egf-like domains followed by fibronectin type III (FNIII) domains and a carboxyterminal domain resembling fibrinogen-b. The smallest Tnc variant contains a sequence of eight FNIII repeats that are included in all Tnc proteins. A large number of isoforms can be generated by the inclusion of up to six (mouse), seven (rat, Garwood et al., 2012), or nine (human) additional alternatively spliced FNIII domains between the fifth and sixth FNIII domains of the basic structure. In mice, up to 27 Tnc-isoforms have been described so far, suggesting a combinatorial code (Joester and Faissner, 1999; von Holst et al., 2007). The alternatively spliced domains A1, A2, A4, B, C, and $\mathrm{D}$ expressed in mouse encode diverse functions by themselves, which indicates that the combinatorial variation is functionally relevant (Faissner, 1997b; Joester and Faissner, 2001; Tucker et al., 2006). It is tempting to speculate that binding and availability of the EGF might depend on the splice variants of Tnc as structural folding might also change the availability of the bound EGF. This could lead to direct changes in the amounts of EGF in the intracellular space and therefore lead to changes in the response to this factor.

In the developing CNS, Tnc is first expressed by radial glia and later primarily by astrocytes, where it seems to exert autocrine effects that regulate the proliferation of astrocyte progenitor cells (Karus et al., 2011). Tnc modulates the stem cell compartment in the niche, where it is specifically enriched in the environment of mouse NSPCs at embryonic day E14-E15 (von Holst et al., 2007). For example, tenascin-C contributes to the maturation of NSPCs (Garcion et al., 2004) and to the proliferation and maintenance of oligodendrocyte precursors (Garcion et al., 2001; Garwood et al., 2004; Czopka et al., 2009). The gene Sam68 is a Tnc-regulated target and involved in the control of NSPC proliferation (Moritz et al., 2008). In vivo and in vitro studies demonstrate that Tnc encodes permissive as well as inhibitory cues and thereby mediates neuron migration and axon growth and guidance in the context of neuron-glia interactions (Faissner and Kruse, 1990; Lochter et al., 1991; Husmann et al., 1992;Götz et al., 1996, 1997; Meiners and Geller, 1997; Meiners et al., 1999).

Tnc expression is down-regulated in the adult CNS, with the exception of the canonic neurogenic zones and regions of plasticity in the hypothalamus (Theodosis et al., 1997). In stab wound and knife-cut injuries, however, a subset of GFAP-positive reactive astrocytes up-regulate Tnc (McKeon et al., 1991; Laywell et al., 1992; Brodkey et al., 1995; Zhang et al., 1997; Tang et al., 2003; Dobbertin et al., 2010). Interestingly, the transcription factor Pax6 is also expressed in CNS lesions (Sirko et al., 2009) and induces the preferential up-regulation of the large alternatively spliced Tncisoforms in vitro (von Holst et al., 2007). Enhanced Tnc expression is also observed in gliomas, in non-invasive laser lesions (Sirko et al., 2009), in the dentate gyrus after unilateral entorhinal cortex lesion (Deller et al., 1997) or the hippocampus after injection of kainic acid (Niquet et al., 1995; Nakic et al., 1996). The cytokines FGF2 and TGF- $\beta$ that have been implicated in scar formation both induce Tnc expression in astrocyte cultures (Meiners et al., 1993; Mahler et al., 1997; Smith and Hale, 1997; Flanders et al., 1998; Smith et al., 2001). The question whether distinct isoform variants are selectively regulated has been examined in detail in knife cut wounds inflicted in the adult CNS, an established forebrain injury model. While the small isoform dominated in the resting CNS we observed a 25-fold injury-induced increase of the spliced paired TNfnBD-containing isoforms. Interestingly, transforming 
growth factor- $\beta 1$ (TGF- $\beta 1$ ) as well as TGF- $\beta 1$ in conjunction with FGF2 induced a strong increase of D-containing Tnc isoforms in the ECM of astrocyte monolayers in culture (Dobbertin et al., 2010).

\section{FUNCTIONAL IMPLICATIONS OF UP-REGULATION OF TnC IN CENTRAL NERVOUS SYSTEM WOUNDS}

The expression of the large Tnc-isoforms correlates with periods of increased axonal growth in the developing CNS (Prieto et al., 1990; Bartsch et al., 1992; Joester and Faissner, 2001). Most of the Tnc splice variants in the developing brain contain the FNIII domain TNfnD which promotes neurite outgrowth in all neurons tested so far (Götz et al., 1996; Rigato et al., 2002; Siddiqui et al., 2008; Michele and Faissner, 2009). A peptide encoded in domain TNfnD has been reported to stimulate axon growth in an $\alpha 7 \beta 1$ integrin-dependent manner (Meiners et al., 2001; Mercado et al., 2004). Thus, the enrichment of Tnc isoforms containing the TNfnBD or TNfnD6 domains may create an environment favorable to axonal growth. This interpretation is consistent with a recent study reporting that $\mathrm{Tnc}$ retards retrograde degeneration in a spinal cord injury model and that the TNfnD-domain is required for this effect (Chen et al., 2010; Yu et al., 2011).

On the other hand, Tnc alternating with laminin-1 stripes exerts a strong repulsive effect on growth cones at the boundary separating it from the promoting substrate in a choice assay (Faissner and Kruse, 1990; Taylor et al., 1993; Götz et al., 1996). Using domains heterologously expressed in bacteria we could show that both the TNegf-type repeats and the alternatively spliced $\mathrm{TNfnA}_{1} \mathrm{~A}_{2} \mathrm{~A}_{4}$ domains are repulsive in this assay (Götz et al., 1996). Consistent with these observations, sprouting axons do not penetrate the Tnc-rich denervated outer molecular layer of the rat fascia dentate after entorhinal lesion (Deller et al., 1997). Tnc-up-regulation has also been proposed to inhibit terminal sprouting of mossy fibers in kainate-treated hippocampus (Niquet et al., 1995). Boundaries formed by Tnc-containing ECM have also been observed in developing tissues (Faissner and Steindler, 1995; Treloar et al., 2009).

\section{SOLUBLE FACTORS INFLUENCING ASTROCYTES IN HEALTH AND DISEASE}

Astrocytes can secrete and respond to a number of important cytokines affecting the cellular state of surrounding cells, such as microglia and neurons, and astrocytes themselves. Factors, such as Interleukin-6 (IL-6), Interleukin-1 $\beta$ (IL-1 $\beta$ ), TGF- $\beta 1$, and Tumor necrosis factor $\alpha(\mathrm{TNF} \alpha)$ can act to up regulate or down regulate other pro- and anti-inflammatory genes including COX-2 and NOS-2. Astrocytes also play an important role in secretion of trophic factors such as glial cell line-derived neurotrophic factor (GDNF), brain-derived neurotrophic factor (BDNF), nerve growth factor (NGF), or basic fibroblast growth factor (bFGF or FGF2). Astrocytes can promote neuronal and oligodendrocyte survival by secretion of such factors and can also promote myelination and thereby influence maturation of oligodendrocytes. Therefore, analysis and targeting of growth factor release to promote survival and maintenance of adjacent cells like neurons is an important function that still has to be further analyzed. Here, we further focus on the role of the activated signaling cascades that may have impact on diseases concerning the released factors of astrocytes.

\section{CNTF, IL-6, AND STAT3 SIGNALING}

Ciliary neurotrophic factor (CNTF) is a cytokine that can be produced by glia of the CNS and PNS and in terms of signaling can be mimicked in its action (Stöckli et al., 1989, 1991) CNTF signals through the LIF-Receptor- $\beta /$ gp 130 receptor, which, among others elicits activation of the JAK/Stat pathway and therefore leads to changes in gene expression mainly through the activation of STAT3 (Nakashima et al., 1999). Activation of STAT3 through only gp130 by Interleukin-6 (IL-6) signaling is known to trigger reactive astrogliosis (Sofroniew, 2009). The role of IL-6 is ambivalent, depending on the animal model and the disease that occurs in the experimental paradigms (Campbell et al., 1993; Penkowa et al., 2003; Quintana et al., 2009).

STAT3 is an early trigger for astrogliosis in astrocytes (Sriram et al., 2004). In a mouse model of 1-methyl-4-phenyl1,2,3,6-tetrahydropyridine (MPTP)-induced striatal degeneration, gp 130-related cytokines (e.g., IL-6, CNTF) were up regulated prior to STAT3 activation and nuclear translocation. These events also involve up regulation of GFAP expression, and GFAP mRNA and protein therefore can be used as a marker in astrogliosis (Nakashima et al., 1999; Yanagisawa et al., 1999). STAT3 is not the only trigger for astrogliosis, but it seems to be required for it to occur, at least in the case of spinal cord injury. Ablating STAT3 signals in astrocytes as a consequence leads to attenuated GFAP expression and diminishes astrocyte glial scar formation, compared with Stat 3 wild type astrocytes in mice (Herrmann et al., 2008). In this light, experiments ablating STAT3 in neurons showing that motoneuron survival is significantly reduced after facial nerve lesion in the adult (Schweizer et al., 2002) might also be influenced by less active astrocytes as the astrocytes might have been less activated by missing signals from the lesioned motoneurons. Overall, further study of CNTF, IL-6, and STAT3 signaling pathways might be interesting as it further clarifies the concert interaction of astrocytes, other glial cells, and last not least neurons.

\section{GDNF SIGNALING}

Astrocytes are the major source for GDNF upon brain injury (Bresjanac and Antauer, 2000; Nakagawa and Schwartz, 2004). It also may be responsible for maintenance of GDNF levels in the substantia nigra of Parkinson patients (Mogi et al., 2001). Therefore it may also contribute to a survival scenario toward neuronal survival. While neuronal expression of GDNF under pathophysiological conditions appears to be uncontrollable and widespread also toward the contralateral side of a lesioned brain, astrocytic expression of GDNF exerts a strictly local function (Drinkut et al., 2011). Especially GDNF shows an application dependent function as intrathecal injection of the factor did not significantly improve late stage Parkinsons disease (PD) patients (Lang et al., 2006; Marks et al., 2010), while astrocytic delivery of GDNF proved to be efficient at least in a mouse model (Drinkut et al., 2011). Local administration of neurotrophic support therefore appears to be a possible solution to the general problem of administration of trophic factors that in the past caused various side effects or proved to be insufficient (Sendtner et al., 1995; Ochs et al., 2000). 


\section{NF-KB SIGNALING}

$\mathrm{NF}-\kappa \mathrm{B}$ is a mediator of transcriptional induction for various inflammatory cytokines/factors like IL-6 (Spooren et al., 2010) and NOS-2. It translocates to the nucleus, and binds to its NF- $\kappa \mathrm{B}$ consensus sequence. NF- $\kappa \mathrm{B}$ can be activated by pro-inflammatory mediators, including LPS, TNF $\alpha$, and IL- $1 \beta$. The classical and endogenous activator is IL- $1 \beta$. Inhibition of NF- $\kappa \mathrm{B}$ in astrocytes is reported to ameliorate inflammation and improves recovery after spinal cord injury (Brambilla et al., 2005).

\section{TGF- $\beta 1$ AND SMAD SIGNALING}

The cytokine TGF- $\beta 1$ is generally expressed at low to undetectable levels in the brain, but it is strongly up regulated under neuropathological conditions in various neurologic diseases (Kiefer et al., 1993a,b, 1995; Morgan et al., 1993; Wang et al., 1995; Peress et al., 1996; Vawter et al., 1996; Ata et al., 1997; Krupinski et al., 1998; De Groot et al., 1999; Ali et al., 2001; Zetterberg et al., 2004). TGF- $\beta 1$ signals by binding to TGF $\beta$ RII. The receptor heterodimerizes with and phosphorylates the TGF $\beta$ signaling receptor TGF $\beta$ RI. It then activates activin-like kinase 5 or 1 (ALK5, ALK1), and initiates an intracellular serine/threonine kinase signaling cascade. While ALK1 phosphorylates SMAD1/5/8, ALK5 phosphorylates mothers against decapentaplegic homologs $2 / 3$ (SMAD2/3) which results in nuclear translocation of signaling complexes that change gene expression pattern (Miyazawa et al., 2002).

The effects of TGF- $\beta 1$ in the brain appear to be dependent on the disease which is examined. There are reports on the neuroprotective role of TGF- $\beta 1$ as well as there are reports that show its pro-inflammatory and neuropathological role. In general the effects are widespread and appear to be context-dependent with respect to the disease or disorder examined. An extensive literature has clearly demonstrated a neuroprotective role (Prehn et al., 1993; Henrich-Noack et al., 1996; Mattson et al., 1997; Wyss-Coray et al., 1997;Burton et al., 2002a,b; Brionne et al., 2003; Buisson et al., 2003). Anyhow there is still a missing link for both of these roles with respect to astrocytic functions. However, TGF$\beta 1$ is known to have various effects on astrocytes, such as gene expression, or up-regulation of the amyloid precursor protein (APP; Amara et al., 1999; Burton et al., 2002a; Lesné et al., 2003) modulation of the astrocyte response to pro-inflammatory mediators (Hamby et al., 2006, 2008) and regulation of astrogliosis via increasing GFAP expression, eliciting hypertrophy, and facilitating glial scar formation through up regulation of ECM molecules (ECM; i.e., CSPGs, fibronectin, laminin; Smith and Strunz, 2005). These ECM molecules, especially the CSPGs produced by astrocytes have been investigated in concert with nerve cells to elucidate the diverse functional aspects in terms of neurite growth and survival. Sofar it is known by now that the protein core unit and the glycosaminoglycan chains as well as possibly also the sulfation of these molecules might have even contradictory impact on survival and neurite growth (Conrad et al., 2011; Klausmeyer et al., 2011). Consistent with the effects of TGF- $\beta 1$ on ECM formation, mice that lack Smad3, the downstream effector of TGF- $\beta 1$ signaling through ALK5, exhibit a faster rate of wound closure after stab injury to the brain, compared with control mice (Wang et al., 2007). Future elucidation of regulatory molecules in response to TGF- $\beta 1$ signaling in the brain pathway should prove a more detailed picture of the concert activities and the role for astrocytes in this signaling concert.

\section{NUCLEOTIDES AND THEIR RECEPTORS}

In addition to their many essential intracellular functions, the nucleotides ATP, ADP, and adenosine have functions as extracellular signaling molecules. Nucleotides like ATP or ADP can exert their activities on various cell types within the body and they act through different specific plasma membrane receptors, the purinoceptors $\mathrm{P} 2 \mathrm{X}$ and $\mathrm{P} 2 \mathrm{Y}$, and the adenosine receptors (Khakh and North, 2006). ATP signaling triggers elevation in cytosolic calcium in astrocytes (Bowser and Khakh, 2007; Halassa et al., 2009a; Shigetomi et al., 2010) may even function in sleep modulation influenced by astrocytes (Halassa et al., 2009 b) and leads to gene expression changes associated with reactive astrogliosis after trauma-induced cell injury in vitro (Neary et al., 2003, 2004; Wanner et al., 2008). The molecular pharmacology of P2X, P2Y, and adenosine involves a number of inhibitors and activators, and some of these are being studied for effects on reactive astrogliosis and CNS injury and repair after traumatic injuries such as spinal cord injury (Wang et al., 2004; Peng et al., 2009). This will be a promising area for future exploration.

\section{ASTROCYTIC FUNCTIONS IN NEUROLOGICAL DISEASES}

Astroglial cells are involved in neurological diseases by determination of progression and outcome in neuropathological processes. Astrocytes are involved in various neurodegenerative diseases, including Alzheimer's disease (AD), $\mathrm{PD}$, and amyotrophic lateral sclerosis (ALS; Harvey et al., 2010). Recent evidence suggests that early stages of neurodegenerative processes are accompanied with atrophy of astroglia, which causes disruptions in synaptic connectivity, misbalance in neurotransmitter homeostasis, and neuronal death. At later stages, astrocytes become activated and contribute to the neuroinflammatory component of neurodegeneration.

In the pathology of $\mathrm{AD} \mathrm{A} \beta$ can act as a neurotoxic protein that disrupts calcium signaling in neurons and alters synaptic plasticity (Boillée et al., 2006; Vincent et al., 2010). These effects can lead to loss of synapses, and therefore a dysfunction in the neural network. Protection against AD therefore seems to be in part regulated by environmental cues like higher education. However, the precise mechanism by which $A \beta$ causes neurodegeneration is still not clear. The role of astrocytes in early cognitive decline is a major component of disease pathology (Agostinho et al., 2010; Balducci and Forloni, 2010; Vincent et al., 2010). A $\beta$ can disrupt astrocytic calcium signaling and gliotransmitter release, processes that are vital for astrocyte-neuron communication (Vincent et al., 2010). Therefore, astrocyte dysfunction may contribute to the earliest neuronal deficits in $\mathrm{AD}$.

The role of astrocytes in the early pathogenesis of PD has not been fully characterized so far; but astrogliosis was detected at the late stages of the disease (McGeer and McGeer, 2008; Mena and García de Yébenes, 2008; Solano et al., 2008). At the same time the substantia nigra, in which PD pathology primarily develops, has a low density of astrocytes compared to other brain regions so that early astroglial atrophy and especially mitochondrial pathology 
may have a pathological significance that has not been able to be completely understood so far (Stichel et al., 2007; Schmidt et al., 2011). Astrocyte degeneration can result in diminished support for dopaminergic neurons and therefore be associated with an increased vulnerability. However, this is still a hypothesis to be tested.

Neuron-glial interactions also play an important role in ALS pathology. Prominent astroglial degeneration and atrophy was found in the human SOD1G93A transgenic mouse model. The astrocyte degeneration included both neuronal death and the appearance of clinical symptoms (Rossi et al., 2008; Rossi and Volterra, 2009). The ALS astrocytes in mice (expressing the human SOD1) were more sensitive to glutamate, and displayed a glutamate excitotoxicity (Rossi et al., 2008; Rossi and Volterra, 2009). Even more important, the selective silencing of the SOD1 mutant gene in astrocytes significantly slowed the progression of ALS in transgenic mice (Yamanaka et al., 2008). Late stages of ALS are also characterized by significant astrogliosis and astrocyte proliferation (McGeer and McGeer, 2008).

\section{REFERENCES}

Agostinho, P., Cunha, R. A., and Oliveira, C. (2010). Neuroinflammation, oxidative stress and the pathogenesis of Alzheimer's disease. Curr. Pharm. Des. 16, 2766-2778.

Akita, K., von Holst, A., Furukawa, Y., Mikami, T., Sugahara, K., and Faissner, A. (2008). Expression of multiple chondroitin/dermatan sulfotransferases in the neurogenic regions of the embryonic and adult central nervous system implies that complex chondroitin sulfates have a role in neural stem cell maintenance. Stem Cells 26, 798-809.

Ali, C., Docagne, F., Nicole, O., Lesné, S., Toutain, J., Young, A., Chazalviel, L., Divoux, D., Caly, M., Cabal, P., Derlon, J. M., MacKenzie, E. T., Buisson, A., and Vivien, D. (2001). Increased expression of transforming growth factor-beta after cerebral ischemia in the baboon: an endogenous marker of neuronal stress? J. Cereb. Blood Flow Metab. 21, 820-827.

Allen, N. J., and Barres, B. A. (2009). Neuroscience: Glia - more than just brain glue. Nature 457, 675-677.

Amara, F. M., Junaid, A., Clough, R. R., and Liang, B. (1999). TGF-beta(1), regulation of Alzheimer amyloid precursor protein mRNA expression in a normal human astrocyte cell line: mRNA stabilization. Brain Res. Mol. Brain Res. 71, 42-49.

Ata, A. K., Funa, K., and Olsson, Y. (1997). Expression of various TGFbeta isoforms and type I receptor in necrotizing human brain lesions. Acta Neuropathol. 93, 326-333.

Balducci, C., and Forloni, G. (2010). APP transgenic mice: their use and limitations. Neuromolecular Med. 13, 117-137.

Bandtlow, C. E., and Zimmermann, D. R. (2000). Proteoglycans in the developing brain: new conceptual insights for old proteins. Physiol. Rev. 80, 1267-1290.

Bao, X., Mikami, T., Yamada, S., Faissner, A., Muramatsu, T., and Sugahara, K. (2005). Heparin-binding growth factor, pleiotrophin, mediates neuritogenic activity of embryonic pig brain-derived chondroitin sulfate/dermatan sulfate hybrid chains. J. Biol. Chem. 280, 9180-9191.

Bartsch, S., Bartsch, U., Dörries, U., Faissner, A., Weller, A., Ekblom, P., and Schachner, M. (1992). Expression of tenascin in the developing and adult cerebellar cortex. J. Neurosci. 12, 736-749.

Boillée, S., Yamanaka, K., Lobsiger, C. S., Copeland, N. G., Jenkins, N. A., Kassiotis, G., Kollias, G., and Cleveland, D. W. (2006). Onset and progression in inherited ALS determined by motor neurons and microglia. Science 312, 1389-1392.

Bowser, D. N., and Khakh, B. S. (2007). Vesicular ATP is the predominant cause of intercellular calcium waves in astrocytes. J. Gen. Physiol. 129, 485-491.

Bradbury, E. J., Moon, L. D., Popat, R. J., King, V. R., Bennett, G. S., Patel, P. N., Fawcett, J. W., and McMahon, S. B. (2002). Chondroitinase $\mathrm{ABC}$ promotes functional recovery after spinal cord injury. Nature 416, 636-640.

Brambilla, R., Bracchi-Ricard, V., Hu, W. H., Frydel, B., Bramwell, A., Karmally, S., Green, E. J., and

\section{OUTLOOK}

Astrocytes and astrocyte development have gained more and more intensive research focus over the past years. The changes in view on these cells started with the switch to a more global view in terms of a tissue or organ and not in terms of a single cell type therein. Analysis of astrocyte development and changes that lead to specific alterations are of higher interest as pathological situations like lesions, toxic insults, or neurodegenerative diseases show - parallel to what has been shown for neurons already - that astrocytes reexpress markers that have been down regulated. The difference to neurons might be on the first sight the capacity to undergo cell division so that the cells primarily do not undergo apoptosis. Here, extracellular cues are of high importance as they give signals to the cells and may even regulate the availability of survival versus cell death signals by blocking or neutralizing specific factors. To further elucidate the concert action of soluble factors and matrix components that influence on the other hand the expression profile of the developing and mature astrocytes will be of high importance for the future research.

Bethea, J. R. (2005). Inhibition of astroglial nuclear factor kappaB reduces inflammation and improves functional recovery after spinal cord injury. J. Exp. Med. 202, 145-156.

Bresjanac, M., and Antauer, G. (2000). Reactive astrocytes of the quinolinic acid-lesioned rat striatum express GFRalphal as well as GDNF in vivo. Exp. Neurol. 164, 53-59.

Brionne, T. C., Tesseur, I., Masliah, E., and Wyss-Coray, T. (2003). Loss of TGF-beta 1 leads to increased neuronal cell death and microgliosis in mouse brain. Neuron 40, 1133-1145.

Brodkey, J. A., Laywell, E. D., O’Brien, T. F., Faissner, A., Stefansson, K., Dörries, H. U., Schachner, M., and Steindler, D. A. (1995). Focal brain injury and upregulation of a developmentally regulated extracellular matrix protein. J. Neurosurg. 82, 106-112.

Buisson, A., Lesne, S., Docagne, F., Ali, C., Nicole, O., MacKenzie, E. T. and Vivien, D. (2003). Transforming growth factor-beta and ischemic brain injury. Cell. Mol. Neurobiol.23, 539-550.

Burton, T., Liang, B., Dibrov, A., and Amara, F. (2002a). Transforming growth factor-beta-induced transcription of the Alzheimer beta-amyloid precursor protein gene involves interaction between the CTCF-complex and Smads. Biochem. Biophys. Res. Commun. 295, 713-723.

Burton, T., Liang, B., Dibrov, A., and Amara, F. (2002b). Transcriptional activation and increase in expression of Alzheimer's beta-amyloid precursor protein gene is mediated by
TGF-beta in normal human astrocytes. Biochem. Biophys. Res. Commun. 295, 702-712.

Busch, S. A., and Silver, J. (2007). The role of extracellular matrix in CNS regeneration. Curr. Opin. Neurobiol. 17, 120-127.

Cahoy, J. D., Emery, B., Kaushal, A., Foo, L. C., Zamanian, J. L., Christopherson, K. S., Xing, Y., Lubischer, J. L., Krieg, P. A., Krupenko, S. A., Thompson, W. J., and Barres, B. A. (2008). A transcriptome database for astrocytes, neurons, and oligodendrocytes: a new resource for understanding brain development and function. J. Neurosci. 28, 264-278.

Campbell, I. L., Abraham, C. R., Masliah, E., Kemper, P., Inglis, J. D., Oldstone, M. B., and Mucke, L. (1993). Neurologic disease induced in transgenic mice by cerebral overexpression of interleukin 6 . Proc. Natl. Acad. Sci. U.S.A. 90, 10061-10065.

Carulli, D., Laabs, T., Geller, H. M., Fawcett, J. W. (2005). Chondroitin sulfate proteoglycans in neural development and regeneration. Curr. Opin. Neurobiol. 15, 116-120.

Chen, J., Joon Lee, H., Jakovcevski, I., Shah, R., Bhagat, N., Loers, G., Liu, H. Y., Meiners, S., Taschenberger, G., Kügler, S., Irintchev, A., and Schachner, M. (2010). The extracellular matrix glycoprotein tenascin-C is beneficial for spinal cord regeneration. Mol. Ther. 18, 1769-1777.

Chiquet-Ehrismann, R., and Chiquet, M. (2003). Tenascins: regulation and putative functions during pathological stress. J. Pathol. 200, 488-499. 
Chiquet-Ehrismann, R., and Tucker, R. P. (2011). Tenascins and the importance of adhesion modulation. Cold Spring Harb. Perspect. Biol. 3. doi: 10.1101/cshperspect.a004960

Clement, A. M., Nadanaka, S., Masayama, K., Mandl, C., Sugahara, K., and Faissner, A. (1998). The DSD-1 carbohydrate epitope depends on sulfation, correlates with chondroitin sulfate D motifs, and is sufficient to promote neurite outgrowth. J. Biol. Chem. 273, 28444-28453.

Conrad, R., Jablonka, S., Sczepan, T., Sendtner, M., Wiese, S., and Klausmeyer, A. (2011). Lectin-based isolation and culture of mouse embryonic motoneurons. J. Vis. Exp. 55.

Czopka, T., Von Holst, A., Schmidt, G., Ffrench-Constant, C., and Faissner, A. (2009). Tenascin C and tenascin $\mathrm{R}$ similarly prevent the formation of myelin membranes in a RhoAdependent manner, but antagonistically regulate the expression of myelin basic protein via a separate pathway. Glia 57, 1790-1801.

De Groot, C. J., Montagne, L., Barten, A. D., Sminia, P., and Van Der Valk, P. (1999). Expression of transforming growth factor (TGF)-beta1, -beta2, and -beta3 isoforms and TGF-beta type I and type II receptors in multiple sclerosis lesions and human adult astrocyte cultures. J. Neuropathol. Exp. Neurol. 58, 174-187.

De Keyser, J., Mostert, J. P., and Koch, M. W. (2008). Dysfunctional astrocytes as key players in the pathogenesis of central nervous system disorders. J. Neurol. Sci. 267, 3-16.

Deller, T., Haas, C. A., Naumann, T., Joester, A., Faissner, A., and Frotscher, M. (1997). Up-regulation of astrocyte-derived tenascin-C correlates with neurite outgrowth in the rat dentate gyrus after unilateral entorhinal cortex lesion. Neuroscience 81, 829-846.

Dobbertin, A., Czvitkovich, S., Theocharidis, U., Garwood, J., Andrews, M. R., Properzi, F., Lin, R., Fawcett, J. W., and Faissner, A. (2010). Analysis of combinatorial variability reveals selective accumulation of the fibronectin type III domains B and D of tenascin-C in injured brain. Exp. Neurol. 225, 60-73.

Domowicz, M. S., Sanders, T. A., Ragsdale, C. W., and Schwartz, N. B. (2008). Aggrecan is expressed by embryonic brain glia and regulates astrocyte development. Dev. Biol. 315, 114-124.

Drinkut, A., Tereshchenko, Y., Schulz, J. B., Bähr, M., and Kügler, S. (2011).
Efficient gene therapy for Parkinson's disease using astrocytes as hosts for localized neurotrophic factor delivery. Mol. Ther. 20, 534-543.

Evers, M. R., Salmen, B., Bukalo, O., Rollenhagen, A., Bösl, M. R., Morellini, F., Bartsch, U., Dityatev, A., and Schachner, M. (2002). Impairment of L-type $\mathrm{Ca} 2+$ channeldependent forms of hippocampal synaptic plasticity in mice deficient in the extracellular matrix glycoprotein tenascin-C. J. Neurosci. 22, 7177-7194.

Faissner, A. (1997a). The tenascin gene family in axon growth and guidance. Cell Tissue Res. 290, 331-341.

Faissner, A. (1997b). Glial derived extracellular matrix components: important roles in axon growth and guidance. Neuroscientist 3, 371-380.

Faissner, A., Heck, N., Dobbertin, A., and Garwood, J. (2006). DSD-1-Proteoglycan/Phosphacan and receptor protein tyrosine phosphatase-beta isoforms during development and regeneration of neural tissues. Adv. Exp. Med. Biol. 557, 25-53.

Faissner, A., and Kruse, J. (1990). $\mathrm{J} 1 /$ tenascin is a repulsive substrate for central nervous system neurons. Neuron 5, 627-637.

Faissner, A., Pyka, M., Geissler, M., Sobik, T., Frischknecht, R., Gundelfinger, E. D., and Seidenbecher, C. (2010). Contributions of astrocytes to synapse formation and maturation - potential functions of the perisynaptic extracellular matrix. Brain Res. Rev. 63, 26-38.

Faissner, A., Scholze, A., and Götz, B. (1994a). Tenascin glycoproteins in developing neural tissues: only decoration? Perspect. Dev. Neurobiol. 2, 53-66.

Faissner, A., Clement, A., Lochter, A., Streit, A., Mandl, C., and Schachner, M. (1994b). Isolation of a neural chondroitin sulfate proteoglycan with neurite outgrowth promoting properties. J. Cell Biol. 126, 783-799.

Faissner, A., and Steindler, D. (1995). Boundaries and inhibitory molecules in developing neural tissues. Glia 13, 233-254.

Fawcett, J. (2009). Molecular control of brain plasticity and repair. Prog. Brain Res. 175, 501-509.

Fawcett, J. W. (2006a). The glial response to injury and its role in the inhibition of CNS repair. Adv. Exp. Med. Biol. 557, 11-24.

Fawcett, J. W. (2006b). Overcoming inhibition in the damaged spinal cord. J. Neurotrauma 23, 371-383.
Fitch, M. T., and Silver, J. (2008). CNS injury, glial scars, and inflammation: inhibitory extracellular matrices and regeneration failure. Exp. Neurol. 209, 294-301.

Flanders, K. C., Ren, R. F., and Lippa, C. F. (1998). Transforming growth factor-betas in neurodegenerative disease. Prog. Neurobiol. 54, 71-85.

Ford-Perriss, M., Turner, K., Guimond, S., Apedaile, A., Haubeck, H. D., Turnbull, J., and Murphy, M. (2003). Localization of specific heparan sulfate proteoglycans during the proliferative phase of brain development. Dev. Dyn. 227, 170-184.

Galtrey, C. M., Kwok, J. C., Carulli, D., Rhodes, K. E., and Fawcett, J. W. (2008). Distribution and synthesis of extracellular matrix proteoglycans, hyaluronan, link proteins and tenascin- $\mathrm{R}$ in the rat spinal cord. Eur. J. Neurosci. 27, 1373-1390.

Garcion, E., Faissner, A., and ffrenchConstant, C. (2001). Knockout mice reveal a contribution of the extracellular matrix molecule tenascin$\mathrm{C}$ to neural precursor proliferation and migration. Development 128 , 2485-2496.

Garcion, E., Halilagic, A., Faissner, A., and Ffrench-Constant, C. (2004). Generation of an environmental niche for neural stem cell development by the extracellular matrix molecule tenascin C. Development 131, 3423-3432.

Garwood, J., Garcion, E., Dobbertin, A., Heck, N., Calco, V., ffrenchConstant, C., and Faissner, A. (2004). The extracellular matrix glycoprotein tenascin-C is expressed by oligodendrocyte precursor cells and required for the regulation of maturation rate, survival and responsiveness to platelet-derived growth factor. Eur. J. Neurosci. 2004. 20, 2524-2540.

Garwood, J., Rigato, F., Heck, N., and Faissner, A. (2001). Tenascin glycoproteins and the complementary ligand DSD-1-PG/phosphacan structuring the neural extracellular matrix during development and repair. Restor. Neurol. Neurosci. 19, 51-64.

Garwood, J., Schnädelbach, O. Clement, A., Schütte, K., Bach, A., and Faissner, A. (1999). DSD-1proteoglycan is the mouse homolog of phosphacan and displays opposing effects on neurite outgrowth dependent on neuronal lineage. $J$. Neurosci. 19, 3888-3899.

Garwood, J., Theocharidis, U., Calco, V., Dobbertin, A., and Faissner, A.
(2012). Existence of tenascin-C isoforms in rat that contain the alternatively spliced AD1 domain are developmentally regulated during hippocampal development. Cell. Mol. Neurobiol. 32, 279-287.

Gates, M. A., Thomas, L. B., Howard, E. M., Laywell, E. D., Sajin, B., Faissner, A., Götz, B., Silver, J., and Steindler, D. A. (1995). Cell and molecular analysis of the developing and adult mouse subventricular zone of the cerebral hemispheres. J. Comp. Neurol. 361, 249-266.

Götz, B., Scholze, A., Clement, A., Joester, A., Schütte, K., Wigger, F., Frank, R., Spiess, E., Ekblom, P., and Faissner, A. (1996). Tenascin$\mathrm{C}$ contains distinct adhesive, antiadhesive, and neurite outgrowth promoting sites for neurons. J. Cell Biol. 132, 681-699.

Götz, M., Bolz, J., Joester, A., and Faissner, A. (1997). Tenascin-C synthesis and influence on axonal growth during rat cortical development. Eur. J. Neurosci. 9, 496-506.

Gurevicius, K., Kuang, F., Stoenica, L., Irintchev, A., Gureviciene, I., Dityatev, A., Schachner, M., and Tanila, H. (2009). Genetic ablation of tenascin-C expression leads to abnormal hippocampal CA1 structure and electrical activity in vivo. Hippocampus 19, 1232-1246.

Halassa, M. M., Fellin, T., and Haydon, P. G. (2009a). Tripartite synapses: roles for astrocytic purines in the control of synaptic physiology and behavior. Neuropharmacology 57, 343-346.

Halassa, M. M., Florian, C., Fellin, T., Munoz, J. R., Lee, S. Y., Abel, T., Haydon, P. G., and Frank, M. G. (2009b). Astrocytic modulation of sleep homeostasis and cognitive consequences of sleep loss. Neuron 61, 213-219.

Hamby, M. E., Hewett, J. A., and Hewett, S. J. (2006). TGF-betal potentiates astrocytic nitric oxide production by expanding the population of astrocytes that express NOS-2. Glia 54, 566-577.

Hamby, M. E., Hewett, J. A., and Hewett, S. J. (2008). TGF-beta1 reduces the heterogeneity of astrocytic cyclooxygenase-2 and nitric oxide synthase-2 gene expression in a stimulus-independent manner. Prostaglandins Other Lipid Mediat. 85, 115-124.

Harvey, B. K., Richie, C. T., Hoffer, B. J., and Airavaara, M. (2010). Transgenic animal models of neurodegeneration based on human genetic studies. J. Neural Transm. 118, 27-45. 
Henrich-Noack, P., Prehn, J. H., and Krieglstein, J. (1996). TGF-beta 1 protects hippocampal neurons against degeneration caused by transient global ischemia. Dose-response relationship and potential neuroprotective mechanisms. Stroke 27, 1609-1614; discussion 1615.

Herrmann, J. E., Imura, T., Song, B., Qi, J., Ao, Y., Nguyen, T. K., Korsak, R. A., Takeda, K., Akira, S., and Sofroniew, M. V. (2008). STAT3 is a critical regulator of astrogliosis and scar formation after spinal cord injury. $J$. Neurosci. 28, 7231-7243.

Hikino, M., Mikami, T., Faissner, A., Vilela-Silva, A. C., Pavão, M. S., and Sugahara, K. (2003). Oversulfated dermatan sulfate exhibits neurite outgrowth-promoting activity toward embryonic mouse hippocampal neurons: implications of dermatan sulfate in neuritogenesis in the brain. J. Biol. Chem. 278, 43744-43754.

Holley, J. E., Gveric, D., Whatmore, J. L., and Gutowski, N. J. (2005). Tenascin $\mathrm{C}$ induces a quiescent phenotype in cultured adult human astrocytes. Glia 52, 53-58.

Husmann, K., Faissner, A., and Schachner, M. (1992). Tenascin promotes cerebellar granule cell migration and neurite outgrowth by different domains in the fibronectin type III repeats. J. Cell Biol. 116, 1475-1486.

Ida, M., Shuo, T., Hirano, K., Tokita, Y., Nakanishi, K., Matsui, F., Aono, S., Fujita, H., Fujiwara, Y., Kaji, T., and Oohira, A. (2006). Identification and functions of chondroitin sulfate in the milieu of neural stem cells. J. Biol. Chem. 281, 5982-5991.

Irintchev, A., Rollenhagen, A., Troncoso, E., Kiss, J. Z., and Schachner, M. (2005). Structural and functional aberrations in the cerebral cortex of tenascin-C deficient mice. Cereb. Cortex 15, 950-962.

Ishii, M., and Maeda, N. (2008). Oversulfated chondroitin sulfate plays critical roles in the neuronal migration in the cerebral cortex. J. Biol. Chem. 283, 32610-32620.

Ito, Y., Hikino, M., Yajima, Y., Mikami, T., Sirko, S., von Holst, A., Faissner, A., Fukui, S., and Sugahara, K. (2005). Structural characterization of the epitopes of the monoclonal antibodies 473HD, CS-56, and MO225 specific for chondroitin sulfate D-type using the oligosaccharide library. Glycobiology 15, 593-603.

Joester, A., and Faissner, A. (1999). Evidence for combinatorial variability of tenascin-C isoforms and developmental regulation in the mouse central nervous system. J. Biol. Chem. 274, 17144-17151.

Joester, A., and Faissner, A. (2001). The structure and function of tenascins in the nervous system. Matrix Biol. 20, 13-22.

Jones, F. S., and Jones, P. L. (2000). The tenascin family of ECM glycoproteins: structure, function, and regulation during embryonic development and tissue remodeling. Dev. Dyn. 218, 235-259.

Kabos, P., Matundan, H., Zandian, M., Bertolotto, C., Robinson, M. L., Davy, B. E., Yu, J. S., and Krueger, R. C. Jr. (2004). Neural precursors express multiple chondroitin sulfate proteoglycans, including the lectican family. Biochem. Biophys. Res. Commun. 318, 955-963.

Karus, M., Denecke, B., ffrenchConstant, C., Wiese, S., and Faissner, A. (2011). The extracellular matrix molecule tenascin $\mathrm{C}$ modulates expression levels and territories of key patterning genes during spinal cord astrocyte specification. Development 138, 5321-5331.

Kauppinen, R. A., Holopainen, I., Enkvist, K., and Akerman, K. E. (1989). Astroglia - more than a neural glue. Duodecim 105, 498-506.

Kazanis, I., Belhadi, A., Faissner, A., and Ffrench-Constant, C. (2007). The adult mouse subependymal zone regenerates efficiently in the absence of tenascin-C. J. Neurosci. 27, 13991-13996.

Kettenmann, H., and Verkhratsky, A. (2011). [Neuroglia - living nerve glue]. Fortschr. Neurol. Psychiatr. 79, 588-597.

Khakh, B. S., and North, R. A. (2006). P2X receptors as cell-surface ATP sensors in health and disease. Nature $442,527-532$.

Kiefer, R., Gold, R., Gehrmann, J., Lindholm, D., Wekerle, H., and Kreutzberg, G. W. (1993a). Transforming growth factor beta expression in reactive spinal cord microglia and meningeal inflammatory cells during experimental allergic neuritis. J. Neurosci. Res. 36, 391-398.

Kiefer, R., Lindholm, D., and Kreutzberg, G. W. (1993b). Interleukin-6 and transforming growth factor-beta 1 mRNAs are induced in rat facial nucleus following motoneuron axotomy. Eur. J. Neurosci. 5, 775-781.

Kiefer, R., Streit, W. J., Toyka, K. V., Kreutzberg, G. W., and Hartung, H. P. (1995). Transforming growth factor-beta 1: a lesion-associated cytokine of the nervous system. Int. J. Dev. Neurosci. 13, 331-339.
Klausmeyer, A., Conrad, R., Faissner, A., and Wiese, S. (2011). Influence of glial-derived matrix molecules, especially chondroitin sulfates, on neurite growth and survival of cultured mouse embryonic motoneurons. J. Neurosci. Res. 89, 127-141.

Kleene, R., and Schachner, M. (2004). Glycans and neural cell interactions. Nat. Rev. Neurosci. 5, 195-208.

Kornblum, H. I., Hussain, R., Wiesen, J., Miettinen, P., Zurcher, S. D. Chow, K., Derynck, R., and Werb, Z. (1998). Abnormal astrocyte development and neuronal death in mice lacking the epidermal growth factor receptor. J. Neurosci. Res. 53, 697-717.

Krupinski, J., Vodovotz, Y., Li, C. Slowik, A., Beevers, D., Flanders, K. C., Lip, G., Kumar, P., and Szczudlik, A. (1998). Inducible nitric oxide production and expression of transforming growth factor-betal in serum and CSF after cerebral ischaemic stroke in man. Nitric Oxide 2, 442-453.

Kwok, J. C., Afshari, F., García-Alías, G., and Fawcett, J. W. (2008). Proteoglycans in the central nervous system: plasticity, regeneration and their stimulation with chondroitinase ABC. Restor. Neurol. Neurosci. 26, 131-145.

Lang, A. E., Gill, S., Patel, N. K., Lozano, A., Nutt, J. G., Penn, R., Brooks, D. J., Hotton, G., Moro, E., Heywood, P., Brodsky, M. A., Burchiel, K., Kelly, P., Dalvi, A., Scott, B., Stacy, M., Turner, D., Wooten, V. G., Elias, W. J., Laws, E. R., Dhawan, V., Stoessl, A. J., Matcham, J., Coffey, R. J., and Traub, M. (2006). Randomized controlled trial of intraputamenal glial cell line-derived neurotrophic factor infusion in Parkinson disease. Ann. Neurol. 59, 459-466.

Lathia, J. D., Patton, B., Eckley, D. M. Magnus, T., Mughal, M. R., Sasaki, T., Caldwell, M. A., Rao, M. S., Mattson, M. P., and ffrench-Constant, C. (2007). Patterns of laminins and integrins in the embryonic ventricular zone of the CNS. J. Comp. Neurol. 505, 630-643.

Laywell, E. D., Dörries, U., Bartsch, U., Faissner, A., Schachner, M., and Steindler, D. A. (1992). Enhanced expression of the developmentally regulated extracellular matrix molecule tenascin following adult brain injury. Proc. Natl. Acad. Sci. U.S.A. 89, 2634-2638.

Lehre, K. P., Levy, L. M., Ottersen, O. P., Storm-Mathisen, J., and Danbolt, N. C. (1995). Differential expression of two glial glutamate transporters in the rat brain: quantitative and immunocytochemical observations. J. Neurosci. 15(3 Pt 1), 1835-1853.

Lesné, S., Docagne, F., Gabriel, C., Liot, G., Lahiri, D. K., Buée, L., Plawinski, L., Delacourte, A., MacKenzie, E. T., Buisson, A., and Vivien, D. (2003). Transforming growth factor-beta 1 potentiates amyloid-beta generation in astrocytes and in transgenic mice. J. Biol. Chem. 278, 18408-18418.

Lochter, A., Vaughan, L., Kaplony, A., Prochiantz, A., Schachner, M., and Faissner, A. (1991). J1/tenascin in substrate-bound and soluble form displays contrary effects on neurite outgrowth. J. Cell Biol. 113, 1159-1171.

Mahler, M., Ben-Ari, Y., and Represa, A. (1997). Differential expression of fibronectin, tenascin-C and NCAMs in cultured hippocampal astrocytes activated by kainate, bacterial lipopolysaccharide or basic fibroblast growth factor. Brain Res. 775, 63-73.

Maleski, M., and Hockfield, S. (1997). Glial cells assemble hyaluronanbased pericellular matrices in vitro. Glia 20, 193-202.

Marks, W. J. Jr., Bartus, R. T., Siffert, J., Davis, C. S., Lozano, A., Boulis, N. Vitek, J., Stacy, M., Turner, D., Verhagen, L., Bakay, R., Watts, R., Guthrie, B., Jankovic, J., Simpson, R., Tagliati, M., Alterman, R., Stern, M., Baltuch, G., Starr, P. A., Larson, P. S., Ostrem J. L., Nutt, J., Kieburtz, K., Kordower, J. H., and Olanow, C. W. (2010). Gene delivery of AAV2-neurturin for Parkinson's disease: a doubleblind, randomised, controlled trial. Lancet Neurol. 9, 1164-1172.

Massey, J. M., Amps, J., Viapiano, M. S., Matthews, R. T., Wagoner, M. R., Whitaker, C. M., Alilain, W., Yonkof, A. L., Khalyfa, A., Cooper, N. G., Silver, J., and Onifer, S. M. (2008). Increased chondroitin sulfate proteoglycan expression in denervated brainstem targets following spinal cord injury creates a barrier to axonal regeneration overcome by chondroitinase $\mathrm{ABC}$ and neurotrophin-3. Exp. Neurol. 209, 426-445.

Mattson, M. P., Barger, S. W., Furukawa, K., Bruce, A. J., Wyss-Coray, T., Mark, R. J., and Mucke, L. (1997). Cellular signaling roles of TGF beta, TNF alpha and beta APP in brain injury responses and Alzheimer's disease. Brain Res. Brain Res. Rev. 23, 47-61.

McGeer, P. L., and McGeer, E. G. (2008). Glial reactions in Parkinson's disease. Mov. Disord. 23, 474-483.

McKeon, R. J., Schreiber, R. C., Rudge, J. S., and Silver, J. (1991). Reduction of neurite outgrowth in a 
model of glial scarring following CNS injury is correlated with the expression of inhibitory molecules on reactive astrocytes. J. Neurosci. 11, 3398-3411.

Meeuwsen, S., Persoon-Deen, C., Bsibsi, M., Ravid, R., and van Noort, J. M. (2003). Cytokine, chemokine and growth factor gene profiling of cultured human astrocytes after exposure to proinflammatory stimuli. Glia 43, 243-253.

Meiners, S., and Geller, H. M. (1997). Long and short splice variants of human tenascin differentially regulate neurite outgrowth. Mol. Cell. Neurosci. 10, 100-116.

Meiners, S., Marone, M., Rittenhouse, J. L., and Geller, H. M. (1993). Regulation of astrocytic tenascin by basic fibroblast growth factor. Dev. Biol. $160,480-493$.

Meiners, S., Mercado, M. L., Nure-Kamal, M. S., and Geller, H. M. (1999). Tenascin-C contains domains that independently regulate neurite outgrowth and neurite guidance. J. Neurosci. 19, 8443-8453.

Meiners, S., Nur-e-Kamal, M. S., and Mercado, M. L. (2001). Mercado, Identification of a neurite outgrowth-promoting motif within the alternatively spliced region of human tenascin-C. J. Neurosci. 21, 7215-7225.

Mena, M. A., and García de Yébenes, J. (2008). Glial cells as players in parkinsonism: the "good," the "bad," and the "mysterious" glia. Neuroscientist 14, 544-560.

Mercado, M. L., Nur-e-Kamal, A., Liu, H. Y., Gross, S. R., Movahed, R., and Meiners, S. (2004). Neurite outgrowth by the alternatively spliced region of human tenascin-C is mediated by neuronal alpha7betal integrin. J. Neurosci. 24, 238-247.

Michele, M., and Faissner, A. (2009). Tenascin-C stimulates contactindependent neurite outgrowth via activation of phospholipase C. Mol. Cell. Neurosci. 2009. 41, 397-408.

Milev, P., Monnerie, H., Popp, S., Margolis, R. K., and Margolis, R. U. (1998). The core protein of the chondroitin sulfate proteoglycan phosphacan is a high-affinity ligand of fibroblast growth factor- 2 and potentiates its mitogenic activity. J. Biol. Chem. 273, 21439-21442.

Miyazawa, K., Shinozaki, M., Hara, T., Furuya, T., and Miyazono, K. (2002). Two major Smad pathways in TGFbeta superfamily signalling. Genes Cells 7, 1191-1204.

Mogi, M., Togari, A., Kondo, T., Mizuno, Y., Kogure, O., Kuno, S., Ichinose, H., and Nagatsu, T. (2001). Glial cell line-derived neurotrophic factor in the substantia nigra from control and parkinsonian brains. Neurosci. Lett. 300, 179-181.

Morgan, T. E., Nichols, N. R., Pasinetti, G. M., and Finch, C. E. (1993). TGF-beta 1 mRNA increases in macrophage/microglial cells of the hippocampus in response to deafferentation and kainic acid-induced neurodegeneration. Exp. Neurol. 120, 291-301.

Moritz, S., Lehmann, S., Faissner, A., and von Holst, A. (2008). An induction gene trap screen in neural stem cells reveals an instructive function of the niche and identifies the splicing regulator sam 68 as a tenascin-Cregulated target gene. Stem Cells 26, 2321-2331.

Nadanaka, S., Clement, A., Masa@@@yama, K., Faissner, A., and Sugahara, K. (1998). Characteristic hexasaccharide sequences in octasaccharides derived from shark cartilage chondroitin sulfate D with a neurite outgrowth promoting activity. J. Biol. Chem. 273, 3296-3307.

Nagelhus, E. A., Mathiisen, T. M., and Ottersen, O. P. (2004). Aquaporin-4 in the central nervous system: cellular and subcellular distribution and coexpression with KIR4.1. Neuroscience $129,905-913$.

Nakagawa, T., and Schwartz, J. P. (2004). Gene expression profiles of reactive astrocytes in dopaminedepleted striatum. Brain Pathol. 14, 275-280.

Nakashima, K., Wiese, S., Yanagisawa, M., Arakawa, H., Kimura, N., Hisatsune, T., Yoshida, K., Kishimoto, T., Sendtner, M., and Taga, T. (1999). Developmental requirement of gp130 signaling in neuronal survival and astrocyte differentiation. $J$. Neurosci. 19, 5429-5434.

Nakic, M., Mitrovic, N., Sperk, G., and Schachner, M. (1996). Kainic acid activates transient expression of tenascin-C in the adult rat hippocampus. J. Neurosci. Res. 44, 355-362.

Nash, B., Thomson, C. E., Linington, C., Arthur, A. T., McClure, J. D., McBride, M. W., and Barnett, S. C. (2011). Functional duality of astrocytes in myelination. J. Neurosci. 31, 13028-13038.

Neary, J. T., Kang, Y., and Shi, Y. F. (2004). Signaling from nucleotide receptors to protein kinase cascades in astrocytes. Neurochem. Res. 29, 2037-2042.

Neary, J. T., Kang, Y., Willoughby, K. A., and Ellis, E. F. (2003). Activation of extracellular signal-regulated kinase by stretch-induced injury in astrocytes involves extracellular ATP and P2 purinergic receptors. J. Neurosci. 23, 2348-2356.

Nicholson, C., and Sykova, E. (1998). Extracellular space structure revealed by diffusion analysis. Trends Neurosci. 21, 207-215.

Niquet, J., Jorquera, I., Faissner, A., BenAri, Y., and Represa, A. (1995). Gliosis and axonal sprouting in the hippocampus of epileptic rats are associated with an increase of tenascin- $\mathrm{C}$ immunoreactivity. J. Neurocytol. 24 611-624.

Ochs, G., Penn, R. D., York, M., Giess, R., Beck, M., Tonn, J., Haigh, J., Malta, E., Traub, M., Sendtner, M., and Toyka, K. V. (2000). A phase I/II trial of recombinant methionyl human brain derived neurotrophic factor administered by intrathecal infusion to patients with amyotrophic lateral sclerosis. Amyotroph. Lateral. Scler. Other Motor Neuron Disord. 1 , 201-206.

Peng, W., Cotrina, M. L., Han, X., Yu, H., Bekar, L., Blum, L., Takano, T., Tian, G. F., Goldman, S. A., and Nedergaard, M. (2009). Systemic administration of an antagonist of the ATPsensitive receptor $\mathrm{P} 2 \times 7$ improves recovery after spinal cord injury. Proc. Natl. Acad. Sci. U.S.A. 106 12489-12493.

Penkowa, M., Camats, J., Hadberg, H., Quintana, A., Rojas, S., Giralt, M., Molinero, A., Campbell, I. L., and Hidalgo, J. (2003). Astrocytetargeted expression of interleukin6 protects the central nervous system during neuroglial degeneration induced by 6 -aminonicotinamide. $J$. Neurosci. Res. 73, 481-496.

Peress, N. S., Perillo, E., and Seidman, R. J. (1996). Glial transforming growth factor (TGF)-beta isotypes in multiple sclerosis: differential glial expression of TGF-beta 1,2 and 3 isotypes in multiple sclerosis. $\mathrm{J}$. Neuroimmunol. 71, 115-123.

Pizzorusso, T., Medini, P., Berardi, N., Chierzi, S., Fawcett, J. W., and Maffei, L. (2002). Reactivation of ocular dominance plasticity in the adult visual cortex. Science 298, 1248-1251.

Prehn, J. H., Backhauss, C., and Krieglstein, J. (1993). Transforming growth factor-beta 1 prevents glutamate neurotoxicity in rat neocortical cultures and protects mouse neocortex from ischemic injury in vivo. J. Cereb. Blood Flow Metab. 13, 521-525.

Prieto, A. L., Jones, F. S., Cunningham, B. A., Crossin, K. L., and Edelman, G. M. (1990). Localization during development of alternatively spliced forms of cytotactin mRNA by in situ hybridization. J. Cell Biol. 111, 685-698.

Properzi, F., Carulli, D., Asher, R. A., Muir, E., Camargo, L. M., van Kuppevelt, T. H., ten Dam, G. B., Furukawa, Y., Mikami, T., Sugahara, K., Toida, T., Geller, H. M., and Fawcett, J. W. (2005). Chondroitin 6-sulphate synthesis is up-regulated in injured CNS, induced by injuryrelated cytokines and enhanced in axon-growth inhibitory glia. Eur. J. Neurosci. 21, 378-390.

Quintana, A., Müller, M., Frausto, R. F., Ramos, R., Getts, D. R., Sanz, E., Hofer, M. J., Krauthausen, M., King, N. J., Hidalgo, J., and Campbell, I. L. (2009). Site-specific production of IL-6 in the central nervous system retargets and enhances the inflammatory response in experimental autoimmune encephalomyelitis. $J$. Immunol. 183, 2079-2088.

Rauch, U., Clement, A., Retzler, C., Fröhlich, L., Fässler, R., Göhring, W., and Faissner, A. (1997). Mapping of a defined neurocan binding site to distinct domains of tenascin-C. $J$. Biol. Chem. 272, 26905-26912.

Rigato, F., Garwood, J., Calco, V., Heck, N., Faivre-Sarrailh, C., and Faissner, A. (2002). Tenascin-C promotes neurite outgrowth of embryonic hippocampal neurons through the alternatively spliced fibronectin type III BD domains via activation of the cell adhesion molecule $\mathrm{F} 3 /$ contactin. J. Neurosci. 22, 6596-6609.

Rossi, D., Brambilla, L., Valori, C. F., Roncoroni, C., Crugnola, A., Yokota, T., Bredesen, D. E., and Volterra, A. (2008). Focal degeneration of astrocytes in amyotrophic lateral sclerosis. Cell Death Differ. 15, 1691-1700.

Rossi, D., and Volterra, A. (2009). Astrocytic dysfunction: insights on the role in neurodegeneration. Brain Res. Bull. 80, 224-232.

Schmidt, S., Linnartz, B., Mendritzki, S., Sczepan, T., Lübbert, M., Stichel, C. C., and Lübbert, H. (2011). Genetic mouse models for Parkinson's disease display severe pathology in glial cell mitochondria. Hum. Mol. Genet. 20, 1197-1211.

Schweizer, U., Gunnersen, J., Karch, C., Wiese, S., Holtmann, B., Takeda, K., Akira, S., and Sendtner, M. (2002). Conditional gene ablation of Stat3 reveals differential signaling requirements for survival of motoneurons during development and after nerve injury in the adult. J. Cell Biol. 156, 287-297.

Sendtner, M., Hughes, R. A., Dittrich, F., Holtmann, B., Masu, Y., Carroll, P., 
Ochs, G., Toyka, K. V., and Thoenen, H. (1995). Ciliary neurotrophic factor (CNTF): physiological and pharmacological effects. Restor. Neurol. Neurosci. 8, 95-96.

Shigetomi, E., Kracun, S., Sofroniew, M. V., and Khakh, B. S. (2010). A genetically targeted optical sensor to monitor calcium signals in astrocyte processes. Nat. Neurosci. 13, 759-766.

Siddiqui, S., Horvat-Bröcker, A., and Faissner, A. (2008). The glia-derived extracellular matrix glycoprotein tenascin-C promotes embryonic and postnatal retina axon outgrowth via the alternatively spliced fibronectin type III domain TNfnD. Neuron Glia Biol. 4, 271-283.

Siddiqui, S., Horvat-Broecker, A., and Faissner, A. (2009). Comparative screening of glial cell types reveals extracellular matrix that inhibits retinal axon growth in a chondroitinase $\mathrm{ABC}$-resistant fashion. Glia 57 , 1420-1438.

Silver, J., and Miller, J. H. (2004). Regeneration beyond the glial scar. Nat. Rev. Neurosci. 5, 146-156.

Sirko, S., Neitz, A., Mittmann, T., Horvat-Bröcker, A., von Holst, A., Eysel, U. T., and Faissner, A. (2009). Focal laser-lesions activate an endogenous population of neural stem/progenitor cells in the adult visual cortex. Brain 132( $\mathrm{Pt} 8)$, 2252-2264.

Sirko, S., von Holst, A., Weber, A., Wizenmann, A., Theocharidis, U., Götz, M., and Faissner, A. (2010a). Chondroitin sulfates are required for fibroblast growth factor-2-dependent proliferation and maintenance in neural stem cells and for epidermal growth factor-dependent migration of their progeny. Stem Cells 28, 775-787.

Sirko, S., Akita, K., Von Holst, A., and Faissner, A. (2010b). Structural and functional analysis of chondroitin sulfate proteoglycans in the neural stem cell niche. Meth. Enzymol. 479, 37-71.

Sirko, S., von Holst, A., Wizenmann, A., Götz, M., and Faissner, A. (2007). Chondroitin sulfate glycosaminoglycans control proliferation, radial glia cell differentiation and neurogenesis in neural stem/progenitor cells. Development 134, 2727-2738.

Smith, C., Berry, M., Clarke, W. E., and Logan, A. (2001). Differential expression of fibroblast growth factor-2 and fibroblast growth factor receptor 1 in a scarring and nonscarring model of CNS injury in the rat. Eur. J. Neurosci. 13, 443-456.
Smith, G. M., and Hale, J. H. (1997). Macrophage/microglia regulation of astrocytic tenascin: synergistic action of transforming growth factor-beta and basic fibroblast growth factor. J. Neurosci. 17, 9624-9633.

Smith, G. M., and Strunz, C. (2005). Growth factor and cytokine regulation of chondroitin sulfate proteoglycans by astrocytes. Glia 52, 209-218.

Smith-Thomas, L. C., Fok-Seang, J., Stevens, J., Du, J. S., Muir, E., Faissner, A., Geller, H. M., Rogers, J. H., and Fawcett, J. W. (1994). An inhibitor of neurite outgrowth produced by astrocytes. J. Cell. Sci. 107(Pt 6), 1687-1695.

Smith-Thomas, L. C., Stevens, J., FokSeang, J., Faissner, A., Rogers, J. H., and Fawcett, J. W. (1995). Increased axon regeneration in astrocytes grown in the presence of proteoglycan synthesis inhibitors. J. Cell. Sci. 108(Pt 3), 1307-1315.

Sofroniew, M. V. (2009). Molecular dissection of reactive astrogliosis and glial scar formation. Trends Neurosci. 32, 638-647.

Sofroniew, M. V., and Vinters, H. V. (2009). Astrocytes: biology and pathology. Acta Neuropathol. 119, $7-35$.

Solano, R. M., Casarejos, M. J., Menéndez-Cuervo, J., RodriguezNavarro, J. A., García de Yébenes, J., and Mena, M. A. (2008). Glial dysfunction in parkin null mice: effects of aging. J. Neurosci. 28, 598-611.

Spooren, A., Kooijman, R., Lintermans, B., Van Craenenbroeck, K., Vermeulen, L., Haegeman, G., and Gerlo, S. (2010). Cooperation of NFkappaB and CREB to induce synergistic IL-6 expression in astrocytes. Cell. Signal. 22, 871-881.

Sriram, K., Benkovic, S. A., Hebert, M. A., Miller, D. B., and O'Callaghan, J. P. (2004). Induction of gp130related cytokines and activation of JAK2/STAT3 pathway in astrocytes precedes up-regulation of glial fibrillary acidic protein in the 1-methyl-4-phenyl-1,2,3,6tetrahydropyridine model of neurodegeneration: key signaling pathway for astrogliosis in vivo? J. Biol. Chem. 279, 19936-19947.

Stichel, C. C., Zhu, X. R., Bader, V., Linnartz, B., Schmidt, S., and Lübbert, H. (2007). Mono- and doublemutant mouse models of Parkinson's disease display severe mitochondrial damage. Hum. Mol. Genet. 16, 2377-2393.

Stöckli, K. A., Lillien, L. E., Näher-Noé, M., Breitfeld, G., Hughes, R. A., Raff,
M. C., Thoenen, H., and Sendtner, M. (1991). Regional distribution, developmental changes, and cellular localization of CNTF-mRNA and protein in the rat brain. J. Cell Biol. $115,447-459$.

Stöckli, K. A., Lottspeich, F., Sendtner, M., Masiakowski, P., Carroll, P., Götz, R., Lindholm, D., and Thoenen, H. (1989). Molecular cloning, expression and regional distribution of rat ciliary neurotrophic factor. Nature $342,920-923$.

Strekalova, T., Sun, M., Sibbe, M., Evers, M., Dityatev, A., Gass, P., and Schachner, M. (2002). Fibronectin domains of extracellular matrix molecule tenascin-C modulate hippocampal learning and synaptic plasticity. Mol. Cell. Neurosci. 21, 173-187.

Tang, X., Davies, J. E., and Davies, S. J. (2003). Changes in distribution, cell associations, and protein expression levels of NG2, neurocan, phosphacan, brevican, versican $\mathrm{V} 2$, and tenascin- $\mathrm{C}$ during acute to chronic maturation of spinal cord scar tissue. J. Neurosci. Res. 71, 427-444.

Taylor, J., Pesheva, P., and Schachner, M. (1993). Influence of janusin and tenascin on growth cone behavior in vitro. J. Neurosci. Res. 35 , 347-362.

Theodosis, D. T., Pierre, K., Cadoret, M. A., Allard, M., Faissner, A., and Poulain, D. A. (1997). Expression of high levels of the extracellular matrix glycoprotein, tenascin-C, in the normal adult hypothalamoneurohypophysial system. J. Comp. Neurol. 379, 386-398.

Treloar, H. B., Ray, A., Dinglasan, L. A., Schachner, M., and Greer, C. A. (2009). Tenascin-C is an inhibitory boundary molecule in the developing olfactory bulb. J. Neurosci. 29 , 9405-9416.

Tucker, R. P., Drabikowski, K., Hess, J. F., Ferralli, J., Chiquet-Ehrismann, R. and Adams, J. C. (2006). Phylogenetic analysis of the tenascin gene family: evidence of origin early in the chordate lineage. BMC Evol. Biol. 6 , 60.

Ueoka, C., Kaneda, N., Okazaki, I., Nadanaka, S., Muramatsu, T., and Sugahara, K. (2000). Neuronal cell adhesion, mediated by the heparinbinding neuroregulatory factor midkine, is specifically inhibited by chondroitin sulfate E. Structural ans functional implications of the oversulfated chondroitin sulfate. J. Biol. Chem. 275, 37407-37413.

Vawter, M. P., Dillon-Carter, O., Tourtellotte, W. W., Carvey, P., and Freed,
W. J. (1996). TGFbetal and TGFbeta2 concentrations are elevated in Parkinson's disease in ventricular cerebrospinal fluid. Exp. Neurol. 142, 313-322.

Verma, P., Garcia-Alias, G., and Fawcett, J. W. (2008). Spinal cord repair: bridging the divide. Neurorehabil. Neural. Repair 22, 429-437.

Vincent, A. J., Gasperini, R., Foa, L., and Small, D. H. (2010). Astrocytes in Alzheimer's disease: emerging roles in calcium dysregulation and synaptic plasticity. J. Alzheimers Dis. 22, 699-714.

Virchow, R. (1856). Gesammelte Abhandlungen zur wissenschaftlichen Medicin. Frankfurt am: Taf, 1-1024.

Volterra, A., and Meldolesi, J. (2005). Astrocytes, from brain glue to communication elements: the revolution continues. Nat. Rev. Neurosci. 6 , 626-640.

von Holst, A., Egbers, U., Prochiantz, A., and Faissner, A. (2007). Neural stem/progenitor cells express 20 tenascin $\mathrm{C}$ isoforms that are differentially regulated by Pax6. J. Biol. Chem. 282, 9172-9181.

von Holst, A., Sirko, S., and Faissner, A. (2006). The unique 473HDChondroitinsulfate epitope is expressed by radial glia and involved in neural precursor cell proliferation. J. Neurosci. 26 4082-4094.

Wang, X., Arcuino, G., Takano, T., Lin, J., Peng, W. G., Wan, P., Li, P., Xu, Q., Liu, Q. S., Goldman, S. A., and Nedergaard, M. (2004). P2 $\times 7$ receptor inhibition improves recovery after spinal cord injury. Nat. Med. 10, 821-827.

Wang, X., Yue, T. L., White, R. F., Barone, F. C., and Feuerstein, G. Z. (1995). Transforming growth factor-beta 1 exhibits delayed gene expression following focal cerebral ischemia. Brain Res. Bull. 36, 607-609.

Wang, Y., Moges, H., Bharucha, Y., and Symes, A. (2007). Smad3 null mice display more rapid wound closure and reduced scar formation after a stab wound to the cerebral cortex. Exp. Neurol. 203, 168-184.

Wanner, I. B., Deik, A., Torres, M., Rosendahl, A., Neary, J. T., Lemmon, V. P., and Bixby, J. L. (2008). A new in vitro model of the glial scar inhibits axon growth. Glia 56, 1691-1709.

Wyss-Coray, T., Masliah, E., Mallory, M., McConlogue, L., Johnson-Wood, K., Lin, C., and Mucke, L. (1997). Amyloidogenic role of cytokine TGFbetal in transgenic mice and in Alzheimer's disease. Nature 389, 603-606. 
Yagi, H., Yanagisawa, M., Suzuki, Y., Nakatani, Y., Ariga, T., Kato, K., and Yu, R. K. (2010). HNK-1 epitopecarrying tenascin-C spliced variant regulates the proliferation of mouse embryonic neural stem cells. J. Biol. Chem. 285, 37293-37301.

Yamanaka, K., Chun, S. J., Boillee, S., Fujimori-Tonou, N., Yamashita, H., Gutmann, D. H., Takahashi, R., Misawa, H., and Cleveland, D. W. (2008). Astrocytes as determinants of disease progression in inherited amyotrophic lateral sclerosis. $\mathrm{Nat}$. $\mathrm{Neu}$ rosci. 11, 251-253.

Yanagisawa, M., Nakashima, K., and Taga, T. (1999). STAT3-mediated astrocyte differentiation from mouse fetal neuroepithelial cells by mouse oncostatin M. Neurosci. Lett. 269, 169-172.

Yu, Y. M., Cristofanilli, M., Valiveti, A., Ma, L., Yoo, M., Morellini, F., and Schachner, M. (2011). The extracellular matrix glycoprotein tenascin-C promotes locomotor recovery after spinal cord injury in adult zebrafish. Neuroscience 183 , 238-250.

Zetterberg, H., Andreasen, N., and Blennow, K. (2004). Increased cerebrospinal fluid levels of transforming growth factor-betal in Alzheimer's disease. Neurosci. Lett. 367, 194-196.

Zhang, Y., Winterbottom, J. K., Schachner, M., Lieberman, A. R., and Anderson, P. N. (1997).
Tenascin-C expression and axonal sprouting following injury to the spinal dorsal columns in the adult rat. J. Neurosci. Res. 49, 433-450.

Zou, P., Zou, K., Muramatsu, H., Ichihara-Tanaka, K., Habuchi, O., Ohtake, S., Ikematsu, S., Sakuma, S., and Muramatsu, T. (2003). Glycosaminoglycan structures required for strong binding to midkine, a heparin-binding growth factor. Glycobiology 13, 35-42.

Conflict of Interest Statement: The authors declare that the research was conducted in the absence of any commercial or financial relationships that could be construed as a potential conflict of interest.
Received: 15 March 2012; accepted: 06 June 2012; published online: 26 June 2012.

Citation: Wiese S, Karus $M$ and Faissner A (2012) Astrocytes as a source for extracellular matrix molecules and cytokines. Front. Pharmacol. 3:120. doi: 10.3389/fphar.2012.00120

This article was submitted to Frontiers in Neuropharmacology, a specialty of Frontiers in Pharmacology.

Copyright (c) 2012 Wiese, Karus and Faissner. This is an open-access article distributed under the terms of the Creative Commons Attribution Non Commercial License, which permits noncommercial use, distribution, and reproduction in other forums, provided the original authors and source are credited. 